This material has been published in CAB Reviews (2014), Vol. 9 issue 19 pp. 1-19, the only accredited archive of the content that has been certified and accepted after peer review. Copyright and all rights therein are retained by CABI. www.cabi.org/CABReviews

CAB Review resubmission

\title{
Biochar an improver of nutrient and soil water availability - what is the evidence?
}

\section{HL Scott ${ }^{1}$, D Ponsonby ${ }^{2}$ CJ Atkinson ${ }^{1 *}$}

${ }^{1}$ Natural Resources Institute, University of Greenwich, Central Avenue, Chatham Maritime, Kent ME4 TB

${ }^{2}$ Ecology Research Group, Canterbury Christ Church University, North Holmes Road, Canterbury, Kent CT1 1QU

*c.j.atkinson@greenwich.ac.uk

Keywords: Biochar nutrient availability water availability soil fertility water holding capacity

\section{Methodology}

CAB Abstracts and Science Direct (keywords biochar, nutrients, water) along with sources at the University of Greenwich were searched to obtain up to date research papers. Personal collections of the corresponding author were obtained from various sources over the past 5 years were also used. 
This material has been published in CAB Reviews (2014), Vol. 9 issue 19 pp. 1-19, the only accredited archive of the content that has been certified and accepted after peer review. Copyright and all rights therein are retained by CABI. www.cabi.org/CABReviews

Abstract

Biochar has consistently been proposed as a way of improving soil fertility by increasing nutrient and soil water availability. This review critically investigates recent literature, focussing particularly on these agronomic aspects of biochar. We clarify the differences between biochar made from plant (plant derived biochar, PDB) and animal feedstock (animal derived biochar, ADB) and show how pyrolysis temperature affects biochar properties. We also tabulate crop yield data against production variables using recent field and greenhouse studies. We find evidence to suggest that ADB supplies many more nutrients than PDB and that, in general, biochar can improve nutrient availability indirectly through changes in $\mathrm{pH}, \mathrm{CEC}$, soil structure, improved fertiliser efficiency, decreased nutrient leaching and may effect nutrient availability by changing nitrogenous gas release and by changing the soil microbial community, which under some circumstances translates into short term, increased crop yield. Few studies however show complete nutrient, especially $\mathrm{N}$ budgets and elaborate on the underlying mechanisms of interaction, especially with regards to microbial induced changes. Also the longevity of the different beneficial effects is questionable as most studies are less than a year long.

A synopsis of the literature concludes that biochar application promotes soil water availability, particularly in soils which are degraded or of low quality. Despite this conclusion it is hard to find studies that have adopted methodologies which are fully appropriate to support this notion such as available water capacity and how this changes in response to crop uptake and soil drying. We conclude that the variability in biochar due to variable feedstock and pyrolysis process, as well as particle size and application method, necessitates and also enables production of specific purposedriven biochars to benefit particular aspects of crop production. 
This material has been published in CAB Reviews (2014), Vol. 9 issue 19 pp. 1-19, the only accredited archive of the content that has been certified and accepted after peer review. Copyright and all rights therein are retained by CABI. www.cabi.org/CABReviews

Introduction

The importance of biochar as a recalcitrant source of carbon sequestration in soils is put to one side [1-3], despite a limited number of quantitative studies describing its long-term behaviour in terrestrial ecosystems [4]. Here we focus on its agricultural opportunities [5-9]. There is considerable interest in trying to understand how biochar application to soil might enhance crop yields [5, 10-16]. Much attention is rightly given to the importance of 'soil health' and its agricultural performance as we are being challenged, globally, to halt the degradation of soils vital in sustaining and increasing our food production.

Numerous studies have alluded to biochar as an improver of soil nutrients and water availability and a small number of studies show that crop yields can be increased $[8,17-23]$. This review, however, shows that the effect on crop yield depends on many factors including feedstock, pyrolysis method, pyrolysis temperature, amount of biochar applied, the application method, the soil type, the crop grown and the climate $[24,25,26]$. This review aims to critique recent literature on the effect of biochar on soil nutrient and water availability rather than simply review. It is considered appropriate here to discuss soil nutrients and soil water availability together as their function is highly dependent on each other and very much influenced by the carbon form and content of the soil [27].

We include in the discussion how the feedstock affects the characteristics of the biochar and find that it is beneficial to separate biochar into two groups - plant derived biochar (PDB) and animal derived biochar (ADB). The effect of increasing the highest temperature reached in the pyrolysis process on the characteristics of biochar such as $\%$ ash, $\mathrm{CEC}, \mathrm{pH}$ and surface area is also clarified. Indirect effects of biochar on soil nutrient availability such as the effect on soil pH, nutrient leaching and the efficacy of applied fertilisers is also discussed. The importance of the diversity and function of soil flora is also considered as a means of promoting or inhibiting nutrient availability and cycling, 
This material has been published in CAB Reviews (2014), Vol. 9 issue 19 pp. 1-19, the only accredited archive of the content that has been certified and accepted after peer review. Copyright and all rights therein are retained by CABI. www.cabi.org/CABReviews

along with a detailed review of the effect of biochar on nitrogenous gas release and its subsequent effect on the $\mathrm{N}$ cycle. Its use as a nutrient carrier of, for example, manures and chemical fertilisers or as a way of supplying ammonia from waste patches is also briefly touched upon. Suggestions that biochar may increase soil water availability are discussed based on observations derived initially from Terra preta and consideration is given to whether this translates into benefits outside these regions and climates. We conclude with an explanation of how the production process creates variability and therefore emphasise the importance of producing biochar with targeted soil function and benefit.

\section{BIOCHAR AS AN IMPROVER OF NUTRIENT AVAILABILITY FOR CROP GROWTH}

\section{Influence of biochar on nutrient availability}

Biochar is known to influence soil nutrients in a number of ways. Firstly, it can release its own compositional available nutrients directly into the soil from its ash content and, depending on feedstock and temperature, from its structure at varying rates. Biochar can contain a number of important plant nutrients which includes $\mathrm{N}, \mathrm{P}, \mathrm{K}, \mathrm{Ca}, \mathrm{Mg}$ and $\mathrm{S}$, as well as micronutrients, all of which may be released at varying rates depending on availability $[20,25,28,29]$. Secondly, it can change the $\mathrm{pH}$ of the soil affecting the availability of the crop nutrients present [30,31]. Thirdly, it can retain nutrients from fertilisers added to biochar amended soil through mechanism such as adsorption and its CEC, apparently reducing their leaching [31-34], and fourthly, it can alter the amount of ammonia $\left(\mathrm{NH}_{3}\right)$ and nitrous oxide $\left(\mathrm{N}_{2} \mathrm{O}\right)$ released by soils, affecting soil nitrogen content [30,32,35-39]. Lastly, biochar may affect nutrients in the soil through changes in microbial and fungal metabolism and diversity which are integral in determining crop nutrient availability and uptake [40-42]. 
This material has been published in CAB Reviews (2014), Vol. 9 issue 19 pp. 1-19, the only accredited archive of the content that has been certified and accepted after peer review. Copyright and all rights therein are retained by CABI. www.cabi.org/CABReviews

Effect of feedstock on nutrient availability: plant derived biochars (PDB) and animal derived biochars (ADB)

Biochar is not a term that simply covers pyrolysed $C$ products derived from plant biomass, it also includes a range of other pyrolysised organic materials including waste, such as poultry litter and sewage sludge $[43,44]$. Biochar is therefore an umbrella term for all pyrolysed organic materials. Each feedstock however results in a unique biochar with different nutrient concentrations and crop availabilities which is mainly to the original elemental composition of the feedstock [20,45]. During this review it became apparent that biochars can be categorised into two general types, those made from plants and those made from animal products. The general differences between plant-derived (PDB) and animal derived biochar (ADB) are shown in Table $1[19,20,25,43-47]$. Plant derived biochars generally have higher \% C compared with animal derived biochars. In a study by Singh et al. [44] Eucalyptus saligna wood biochar (W), poultry litter (PL) and cow manure (CM) biochar all produced at $400^{\circ} \mathrm{C}$ using slow pyrolysis were compared. The wood biochar had a C \% of $697 \mathrm{~g} \mathrm{~kg}^{-1}$ whereas the PL and CM had C \% of 431 and $175 \mathrm{~g} \mathrm{~kg}^{-1}$ respectively. Plant derived biochars also have a low mineral ash content compared to animal-derived biochars. For example, the wood biochar had an ash content of $32 \mathrm{~g} \mathrm{~kg}^{-1}$ whereas the $\mathrm{PL}$ and $\mathrm{CM}$ yielded higher ash contents of 423 and $703 \mathrm{~g} \mathrm{~kg}^{-1}$ respectively. The electrical conductance (EC) of PDB is generally low compared to ADB; W biochar E.C. was $0.09 \mathrm{dS} \mathrm{m}^{-1}$ whereas PL biochar EC was $6.32 \mathrm{dS} \mathrm{m}^{-1}$ and CM was $9.18 \mathrm{dS} \mathrm{m}^{-1}$ [44]. This is a similar trend to that of CEC: W- $39 \mathrm{mmol}_{\mathrm{c}} \mathrm{kg}^{-1}, \mathrm{PL}-172 \mathrm{mmol}_{\mathrm{c}} \mathrm{kg}^{-1}$ and $\mathrm{CM}-208 \mathrm{mmol}_{\mathrm{c}} \mathrm{kg}^{-1}$. In general, PDBs have low $\mathrm{N}$ and $\mathrm{P}$ concentrations relative to ADBs. The wood biochar had $2.1 \mathrm{~g} \mathrm{~kg}^{-1}$ of $\mathrm{N}$ and $\sim 0.1 \mathrm{~kg}$ of $\mathrm{P} \mathrm{g} \mathrm{kg}-1$, while the PL biochar contained $51 \mathrm{~g} \mathrm{~kg}^{-1}$ of $\mathrm{N}$ and $5.7 \mathrm{~g} \mathrm{~kg}^{-1}$ of $\mathrm{P}$ and the $\mathrm{CM}$ biochar had $13.5 \mathrm{~g} \mathrm{~kg}^{-1} \mathrm{~N}$ and $4.3 \mathrm{~g} \mathrm{~kg}^{-1}$ of $\mathrm{P}$ [44]. The concentration of $\mathrm{K}$ in $\mathrm{W}$ was at least 15 times less than the concentration of $\mathrm{K}$ in the $\mathrm{ADB}\left(\mathrm{W} \sim 1.4 \mathrm{~g} \mathrm{~kg}^{-1}\right.$ compared to $\mathrm{PL} \sim 25 \mathrm{~g} \mathrm{~kg}^{-1}$ and $\mathrm{CM} \sim 26 \mathrm{~g} \mathrm{~kg}$ $\left.{ }^{1}\right)$. Concentrations of $\mathrm{S}, \mathrm{Ca}$ and $\mathrm{Mg}$ were also greater in ADB than PDB. The total elemental content of a biochar does not however always reflect the actual concentration of nutrients available for crop growth [20]. In general however PDBs have less much available nutrients than ADBs. The available P 
This material has been published in CAB Reviews (2014), Vol. 9 issue 19 pp. 1-19, the only accredited archive of the content that has been certified and accepted after peer review. Copyright and all rights therein are retained by CABI. www.cabi.org/CABReviews

in $\mathrm{W}$ was much lower than in $\mathrm{PL}$ or $\mathrm{CM}$, e.g. $<0.005 \mathrm{~g} \mathrm{~kg}^{-1}$ of available $\mathrm{P}$ in $\mathrm{W}$ compared to $\sim 1.5$ to2.5

$\mathrm{g} \mathrm{kg}^{-1}$ in the CM and PL. The measured exchangeable $\mathrm{K}$ (soluble), $\mathrm{Mg}$ and $\mathrm{Na}$ was also lower in $E$. saligna wood than PL and CM (W contained $3 \mathrm{mmol}_{\mathrm{c}} \mathrm{kg}^{-1}$, PL $360 \mathrm{mmol}_{\mathrm{c}} \mathrm{kg}^{-1}$ and CM $475 \mathrm{mmol}_{\mathrm{c}} \mathrm{kg}^{-1}$ of exchangeable $\mathrm{K}$ ). Biochar made from grass and leaves can have greater crop nutritional content than present in wood biochars but less than the ADB $[44,45]$. Peanut hull biochar however may be viewed as a slight anomaly to the grouping of PDB versus $A D B$, as although the $\%$ ash, $\% \mathrm{P}$ and $\% \mathrm{~K}$ are lower than $\mathrm{ADBs}$ the $\mathrm{N}$ content can be as high as some $\mathrm{ADB}$, e.g. peanut hull biochar produced at $400^{\circ} \mathrm{C}$ had an ash content of $8.2 \%$ and $30 \mathrm{~g} \mathrm{~kg}^{-1}$ of $\mathrm{N}, 3 \mathrm{~g} \mathrm{~kg}^{-1}$ of $\mathrm{P}$ and $20 \mathrm{~g} \mathrm{~kg}^{-1}$ of $\mathrm{K}$, the $\mathrm{N}$ content being higher than that in the CM biochar [48].

\section{The effect of temperature on the nutrient content and properties of biochar}

At lower temperatures $\left(<500^{\circ} \mathrm{C}\right)$ the feedstock characteristics have a large influence on biochar nutrient content [28]. The concentrations of these key plant nutrients in biochar post-production are however strongly influenced by the pyrolysis method, particularly with respect to the highest temperature reached. Wood heated above $120^{\circ} \mathrm{C}$ shows some thermal decomposition and water loss, while hemicelluloses contained within the wood are degraded at $200-260^{\circ} \mathrm{C}$ and cellulose at $240-350^{\circ} \mathrm{C}$, lignin is degraded at $280-500^{\circ} \mathrm{C}$ [49]. Heating causes some nutrients to volatilize whilst others become concentrated in the biochar $[14,28]$. For wood based biochars, $C$ begins to volatilise at $120^{\circ} \mathrm{C}, \mathrm{N}$ volatilises above $200^{\circ} \mathrm{C}, \mathrm{S}$ above $370^{\circ} \mathrm{C}$ and $\mathrm{K}$ and $\mathrm{P}$ at $700-800^{\circ} \mathrm{C}$. Magnesium, $\mathrm{Ca}$ and $\mathrm{Mn}$ volatilise at temperatures above $1000^{\circ} \mathrm{C}[50]$. Therefore as temperature increases more $\mathrm{C}, \mathrm{N}$ and $\mathrm{S}$ may be volatilised. The change in the availability of micronutrients by increased temperature is due to their low volatility and also by the changes in the biochar composition and its chemical structure caused by the heat [51]. The effect of temperature on the characteristics of a biochar made from one particular feedstock is summarised in Table $2[19,25,28,43-45,52,53]$. For any given biochar derived from a particular feedstock, as temperature increases, the yield of biochar decreases as the $\%$ of ash increases [25]. The \% of $\mathrm{C}$ in the biochar increases with temperature (the exception being 
This material has been published in CAB Reviews (2014), Vol. 9 issue 19 pp. 1-19, the only accredited archive of the content that has been certified and accepted after peer review. Copyright and all rights therein are retained by $C A B I$. www.cabi.org/CABReviews

some $\mathrm{ADBs}$ e.g. PL and $\mathrm{CM}$, where the $\mathrm{C} \%$ can decline slightly). Perhaps more importantly the type of $\mathrm{C}$ in the biochar changes as temperature increases, often with the \% aromatic $\mathrm{C}$ increasing while the aliphatic, labile $\mathrm{C}$ content declines $[52,53]$. There are differences between the way temperature changes \% $N$ in PDB and ADB. In wood, pecan shell (PC) and switchgrass (SG) biochars the \% $N$ increases as the temperature increases $[44,48]$. In ADBs derived from feedstocks high in N, such as waste water sludge and PL, as the temperature increases the $\% \mathrm{~N}$ decreases $[28,43,48]$. In general, the amount of $\mathrm{N}$ conserved in the biochar is inversely proportional to the feedstock $\mathrm{N}$ concentration [28]. As $\mathrm{P}$ has low volatility, $\mathrm{P}$ concentration in general increases with temperature, however available $\mathrm{P}$ in the form of $\mathrm{PO}_{4}{ }^{3-}$ primarily decreases [44,54], exception being $\mathrm{CM}$ biochar available $\mathrm{P}$ did not change with temperature [43]. The $\% \mathrm{~K}$ also increases due to its low volatility and the EC in general increases as pyrolysis temperature increases. In general biochar $\mathrm{pH}$ increases and biochar surface area frequently increases (as aliphatic C decomposes creating biochar porosity) $[44,52]$. Peanut hull biochar produced at $400^{\circ} \mathrm{C}$ and $500^{\circ} \mathrm{C}$ and showed its ash content increased from 8.2 to 9.3\%, pH increased from 7.9 to 8.6 and \% C from 75 to 81 [45]. Poultry litter biochar produced at a greater contrasting temperatures $\left(350\right.$ and $700^{\circ} \mathrm{C}$ ) showed that at the higher temperature $\%$ ash increased ( 36 to 52 ), \% C slightly decreased (46 to 44 as it is an ADB), \% P increased (2.9 to 4.3), \% K increased (5.9 to 8.7) and \% $\mathrm{N}$ decreased ( 4.9 to 2.7 as it is an ADB) and the $\mathrm{pH}$ increased (8.7 to 10.3) respectively.

\section{Nutrient availability and effects of $\mathrm{pH}$}

Feedstock and pyrolysis temperature effect the concentration and the availability of nutrients as described above. Potassium K release dynamics from a hardwood biochar (Acer pseudoplatanus, at $\sim 500^{\circ} \mathrm{C}$, from a ring kiln) was found to be different to the $\mathrm{P}$ release dynamics [20]. The release of $\mathrm{K}$ was rapid due to its high solubility and equated to $20-50 \mathrm{~kg} \mathrm{ha}^{-1}$ in the topsoil at a biochar application rate of $20 \mathrm{t} \mathrm{ha}^{-1}$. The amount of $\mathrm{P}$ release equated to only $2.6 \mathrm{~kg} \mathrm{ha}^{-1}$ however because the release was slower compared to $\mathrm{K}$, the authors suggested that $\mathrm{P}$ availability may continue for a 
This material has been published in CAB Reviews (2014), Vol. 9 issue 19 pp. 1-19, the only accredited archive of the content that has been certified and accepted after peer review. Copyright and all rights therein are retained by CABI. www.cabi.org/CABReviews

number of growing seasons. Measuring the release of nutrients from a biochar is necessary to calculate both the long and short-term impact of biochar on soil fertility and fertiliser use strategy. Beiberman and Harpole [21] concluded, in their meta-analysis of 371 independent studies, that biochar addition to soils resulted in increased soil $\mathrm{K}$ and increase plant $\mathrm{K}$ tissue concentration. They also found, on average, increased soil $\mathrm{P}$ and total soil $\mathrm{N}$ concentrations but no significant increase in plant tissue $\mathrm{N}$ and $\mathrm{P}$ concentrations. This again shows that biochar can increase the content of $\mathrm{N}$ and $\mathrm{P}$ in the soil but this does not always translate into increased $\mathrm{P}$ and $\mathrm{N}$ in the plant due to low availability in some biochar, especially PDB.

Studies have found that many biochars, especially PDBs do not contain enough nutrients to be used as fertilisers in their own right [52] and in fact the addition of biochar by itself without added fertiliser can have negative effects [55]. This can be due to the high C:N ratios of some biochar which can cause $\mathrm{N}$-immobilisation as microbes decompose the labile component of the biochar which may have insufficient $\mathrm{N}$, so utilisation occurs of other soil sources of $\mathrm{N}[38,56]$. Biochar may also adsorb nutrients from soils that are already subject to low fertility, further reducing the availability of nutrients to the crop $[18,34]$.

The release of minerals from more nutrient rich $A D B$ however may be significantly greater compared to PDB, suggesting that these types of biochar could be added to the soils as slow release fertilisers [43,57]. A meta-analysis found PL biochars to have the greatest positive effect on crop productivity [58]. These ADBs, especially when produced at lower temperatures are less recalcitrant and may breakdown releasing their constitutional nutrients $[29,36]$. The $N$ in PDB has been assumed to be of low availability due to their heterocyclic structure [59], however $\mathrm{N}$-availability may be much greater in ADB. The $\mathrm{N}$-available from animal waste biochars contains hydrolysable organic $\mathrm{N}$ such as amino acids [60]. Studies involving biochar produced from plants grown with $\mathrm{N}^{15}$ labelled fertiliser has enabled $\mathrm{N}$ movement to be traced $[29,57]$. When this $\mathrm{N}^{15}$ biochar was applied to soil, the isotope 
This material has been published in CAB Reviews (2014), Vol. 9 issue 19 pp. 1-19, the only accredited archive of the content that has been certified and accepted after peer review. Copyright and all rights therein are retained by CABI. www.cabi.org/CABReviews

was moved from the donor-biochar into the recipient-crop. In a review of $\mathrm{N}$ studies, it was suggested

that the $\mathrm{N}$ directly available from a manure derived biochar feedstock was the main cause for the increase in crop yield [46]. Despite other positive results, an application of a high nutrient biochar, that exceeds required fertiliser rates and unbalances soil nutrients could increase nutrient leaching potential and exceed recommended environmental application rates, for example, in nitrate vulnerable zones (UK, NVZs).

Nutrient additions aside, the effects of biochar $\mathrm{pH}$ can be significant and are implicated in a number of studies where yields increase [23,33]. In acidic soil an increase in $\mathrm{pH}$ can increase the availability of nutrients in the soil (particularly $\mathrm{P}$ ) and decrease exchangeable $\mathrm{Al}^{3+}[21,48,58]$. Meta-analyses shows that the effect of biochar on crop productivity was more pronounced in acidic soils, suggesting that one of the main beneficial effects was an increase in $\mathrm{pH}$ [58]. Depending on the $\mathrm{pH}$ of the soil and its buffering capacity, an increase in $\mathrm{pH}$ can, on the other hand, be deleterious for example, the application of a PL biochar ( $\mathrm{pH}$ 8.4-9.0) to a soil with low buffering capacity, caused a large increase in $\mathrm{pH}$ inducing serious fertility consequences [45].

\section{Biochar prevention of nutrient leaching}

The mechanisms by which biochar decreases nutrient leaching are not fully understood, however its CEC, $\mathrm{pH}$ and its physical structure i.e. surface area and porosity are important components $[18,28,39,43,61]$. Biochars produced at lower temperatures $\left(250-450^{\circ} \mathrm{C}\right)$ contain greater quantities of cellulose, hemicellulose and other more labile organic fractions (as they are only degraded or vaporised at higher temperatures $\sim 500^{\circ} \mathrm{C}$ ), and may have higher CEC which aids nutrient absorption $[25,28,39,41,43,61]$. Conversely, biochars produced at high temperatures, with or without the use of steam activation, can have a highly open and porous structure; low in lignin, cellulose and labile organic C which can also contribute to increasing its nutrient absorption capacity $[28,47,62]$. It is difficult to generalise about which feedstock, pyrolysis method and temperature is best suited to 
This material has been published in CAB Reviews (2014), Vol. 9 issue 19 pp. 1-19, the only accredited archive of the content that has been certified and accepted after peer review. Copyright and all rights therein are retained by CABI. www.cabi.org/CABReviews

optimise the retention of key soil crop nutrients, given the variation in their chemical properties, however a number of studies suggest there are trends which are described in the following text

Biochar has been found to decrease leaching of $\mathrm{NH}_{4}{ }^{+}, \mathrm{NO}_{3}{ }^{-}$and $\mathrm{PO}_{3}{ }^{4-}[32,34,63,64]$. An explanation for the decrease in leaching of the $\mathrm{NH}_{4}{ }^{+}$and $\mathrm{NO}_{3}{ }^{-}$is the adsorption of the $\mathrm{NH}_{4}{ }^{+}$to acidic biochar functional groups [19] and the adsorption of $\mathrm{NO}_{3}{ }^{-}$to basic biochar functional groups. As the $\mathrm{pH}$ of the biochar increases with production temperature, biochars produced at higher temperatures are able to adsorb more $\mathrm{NO}_{3}^{-}$. It is suggested that biochar can only absorb $\mathrm{NO}_{3}^{-}$if it is produced at more than $600^{\circ} \mathrm{C}$ [65] Other reasons for differences in $\mathrm{N}$-adsorption, for example, the physical structure of the biochar (i.e. micropore volume and surface area) were rejected by this researcher due to the absence of any correlative trend with $\mathrm{NO}_{3}{ }^{-}$adsorption.

The adsorption of $\mathrm{NH}_{4}^{+}$has been the subject of many studies. Poultry litter and wood biochars produced at $550^{\circ} \mathrm{C}$ and also $400^{\circ} \mathrm{C}$ showed reduced $\mathrm{NH}_{4}{ }^{+}$leaching from a clay soil with no reduction in $\mathrm{NO}_{3}{ }^{-}$leaching [66]. Biochar produced from a variety of feedstock showed that the absorption of $\mathrm{NH}_{4}{ }^{+}$from the soil solution varied with feedstock type and that an effect on nitrate $\left(\mathrm{NO}_{3}{ }^{-}\right)$or phosphate $\left(\mathrm{PO}_{4}{ }^{3-}\right)$ leaching rate was rare [63]. Reduced leaching of $\mathrm{NH}_{4}{ }^{+}, \mathrm{NO}_{3}{ }^{-}$and $\mathrm{PO}_{4}{ }^{3-}$ by 35,34 and $21 \%$ respectively was however apparent with Brazilian pepperwood biochar (Schinus terebinthifolius, slow pyrolysised, at $600^{\circ} \mathrm{C}$, in a $\mathrm{N}_{2}$ environment). Biochars produced at low temperatures however may also be good at reducing leaching of some nutrients especially P. Application of low temperature $\left(250^{\circ} \mathrm{C}\right)$ biochar from switchgrass decreased the amount of $P$ in the leachate $2-3$ times more than one produced at a higher temperature $\left(500^{\circ} \mathrm{C}\right)$ [64]. The researchers here suggest that reduced leaching was due to the retention of the orthophosphate by surface functional groups, Fe and $\mathrm{Al}$ oxide adsorption and $\mathrm{Ca}$ and $\mathrm{Mg}$ phosphate precipitation [48]. CEC of the biochar is usually implicated in its ability to reduce leaching of the positively charged cation $\mathrm{NH}_{4}{ }^{+}$. Reduced $\mathrm{NH}_{4}{ }^{+}$ leaching appears to be linked to the soil wetting and drying cycles [66]. The implications are that as 
This material has been published in CAB Reviews (2014), Vol. 9 issue 19 pp. 1-19, the only accredited archive of the content that has been certified and accepted after peer review. Copyright and all rights therein are retained by CABI. www.cabi.org/CABReviews

biochar 'ages', its nutrient ion absorption capacity increases due to oxidative reactions on its surface

increasing CEC. This shows that the usefulness of using fresh biochar with low CEC in studies may be questionable and may not reflect biochar behaviour over a longer time period.

The benefits of biochar induced reduced leaching are likely to predominate in nutrient poor acidic soils; however significantly reduced N, P, Mg and Si leaching was found in a fertile Midwestern US agricultural soil with a mixed hardwood biochar (primarily oak (Quercus spp.) and hickory (Carya spp.), slow pyrolysis, charcoal kiln, no temperature given) where leaching of total $\mathrm{N}$ and dissolved $\mathrm{P}$ decreased by 11 and 69\% [67]. The single most obvious limitation of the majority of the leaching studies reviewed here is that they were conducted in disturbed soil columns in the absence of crops, with limitations in the realism and control of the environmental experimental conditions compared to those in the field. Also, without complementary measurements we cannot be sure that the recorded decreases in nutrient leachate were due to a direct decrease in nutrient leaching and not due to for example, a real but unmeasured increase in nitrogenous gas release. In a study by Schomberg et al. [68] the $\mathrm{N}$ content in the leachate from a Ultisol was reduced after application of various biochars, but the soil $\mathrm{N}$ nutrient level was not increased These authors concluded that the high ash biochar used acted to increase in soil surface $\mathrm{NH}_{3}$ volatilisation, which was responsible for the decrease $\mathrm{N}$ in the leachate. Measurements of nitrogenous gas release from the soil along with leachate measurements will provide a more complete and informative description of nutrient cycling. It is particularly interesting and important to develop further quantitative links between nitrogen application, changes in $\mathrm{NO}_{3}{ }^{-}$and $\mathrm{NH}_{4}{ }^{+}$leaching and that of $\mathrm{N}$ loss to the atmosphere.

\section{Biochar as a nutrient carrier}

Recent studies have looked at adding fertiliser e.g. NPK or manure to biochar before adding to soil [69]. Other studies have looked at $\mathrm{N}$ loading of biochar using nitrogen rich sources and waste patches, taking advantage of the ammonia adsorbing property of biochar. When biochar is placed in 
This material has been published in CAB Reviews (2014), Vol. 9 issue 19 pp. 1-19, the only accredited archive of the content that has been certified and accepted after peer review. Copyright and all rights therein are retained by CABI. www.cabi.org/CABReviews

an $\mathrm{N}$ rich environment it can adsorb $\mathrm{NH}_{4}{ }^{+}$and subsequently provide this to plants when soil incorporated [70]. This effect was greater with acidic biochars, concurring with the correlation found between increasing acidic function groups and increasing $\mathrm{NH}_{4}{ }^{+}$adsorption of black carbon [19]. This adsorption can have implications for the use of biochar in conditions where $\mathrm{NH}_{3}$ is high e.g. animal production wastes. The uptake of $\mathrm{NH}_{4}{ }^{+}$by biochar reduces the $\mathrm{NH}_{3}$ emissions from these substances and produces a biochar that can carry and supply N. A wood based, low temperature biochar (Pinus radiata), $350^{\circ} \mathrm{C}$ ), has been found to capture $\mathrm{NH}_{4}{ }^{+}$from ruminant urine, acting as an " $\mathrm{N}$ sponge" and subsequently act as a source of crop $\mathrm{N}$ [71]. Biochar can therefore act as a slow release fertiliser in three different ways: 1 ) it can supply nutrients released from its own structure which is especially so for $A D B$, or 2 ) it can release nutrients added to it by loading it with various fertilisers (manure/NPK), or 3) release nutrients that biochar has adsorbed from waste e.g. urine patches. 2) and 3) may be more relevant to PDB. Further study on these three types of application needs to be pursued, with their subsequent effects on $\mathrm{N}$ soil and crop dynamics and nitrogenous gas release to elucidate the full potential, and consequences, of the agronomic value of biochar application.

\section{Biochar incorporation with fertiliser, effects on crop yield}

Early glasshouse studies showed significantly higher yields of radish (Raphanus sativus) with increasing rates of biochar application (green waste, $450^{\circ} \mathrm{C}, \mathrm{BEST}$ energies pyrolysis) in the presence of $\mathrm{N}$ fertiliser [30]; suggesting that biochar application may improve nitrogen fertiliser use efficiency. Reduced leaching was not alluded to however; the biochar induced an increase in soil pH (and corresponding reduction in exchangeable $\mathrm{Al}_{3}{ }^{+}$), an increase in exchangeable $\mathrm{P}$ and $\mathrm{K}$ and a reduction in soil tensile strength which were implicated in the improved fertiliser availability. These benefits were also generally only apparent at application rates $>50 \mathrm{t} \mathrm{ha}^{-1}$ which would currently be economically unviable. Other glasshouse studies have shown that biochar (whole tree residues, $\left.600^{\circ} \mathrm{C}\right)$ at lower application rates $\left(<50 \mathrm{t} \mathrm{ha}^{-1}\right)$ can reduce fertiliser requirements of radish and wheat without compromising yield, reducing fertiliser cost [31]. A field study found that fertiliser use could 
This material has been published in CAB Reviews (2014), Vol. 9 issue 19 pp. 1-19, the only accredited archive of the content that has been certified and accepted after peer review. Copyright and all rights therein are retained by CABI. www.cabi.org/CABReviews

be reduced without impacting on the yield of field-grown wheat by using biochar (green waste and also 35 year old charcoal, $>500^{\circ} \mathrm{C}$ ) located specifically in the rooting zone, 'banded biochar' [72]. Banding reduced losses of biochar due to wind erosion and the amount needed to obtain effects to approximately $1 \mathrm{t} \mathrm{ha} \mathrm{a}^{-1}$. Measurements of the percentage of the root length colonised by arbuscular mycorrhizal fungi (AMF) significantly increased. The increase in fertiliser efficiency was suggested to be due to the biochar initiated increase in the arbuscular mycorrhizal fungi colonisation of the roots that was found and their beneficial impacts on crop nutrient access and uptake, particularly for P. More recent studies have shown a variety of responses in crop yield, both increases and decreases, as well as, no significant change in yield (Table 3 [22,23,31,33,36,37, 43,64,73-80]. Using a hardwood biochar (oak and hickory sawdust $22 \mathrm{Mg} \mathrm{ha}^{-1}, 500^{\circ} \mathrm{C}$, fast pyrolysis), applied to a calcareous soil, there was no effects found in year one and a negative effect $(-36 \%)$ in the second year on corn silage yield [64].There was a decreased silage total $\mathrm{N}$ and $\mathrm{S}$ concentrations and decreased cumulative uptake of total $\mathrm{N}, \mathrm{Mg}, \mathrm{Cu}, \mathrm{Mn}$ and $\mathrm{S}$, accompanied by general foliar chlorosis. They suggest that this may have been caused by a second year reduction in soil $\mathrm{C}$ mineralisation as observed in other studies using low organic carbon soils [81].

Biochar made from nut shell (Macadamia integrifolia) biochar containing high levels of volatile organic matter (VOM, $225 \mathrm{~g} \mathrm{~kg}^{-1}$ ), with or without fertiliser, reduced the growth of corn (Zea mays) [41]. This was in contrast to the low VOM $\left(63 \mathrm{~g} \mathrm{~kg}^{-1}\right)$ nut shell biochar which, when supplemented with fertiliser, showed a significant positive effect on corn growth. The high VOM biochar caused a decline in soil $\mathrm{NH}_{4}{ }^{+}$and increase in soil respiration compared to the low VOM biochar. The authors proposed that the phenolic compounds and other substances in the high VOM biochars stimulated microbial growth and immobilisation of plant available $\mathrm{N}$.

In a recent review $50 \%$ of their compiled studies observed a short-term positive yield or growth impact, $30 \%$ showed no differences and $20 \%$ noted a negative yield or growth effect [19]. The 
This material has been published in CAB Reviews (2014), Vol. 9 issue 19 pp. 1-19, the only accredited archive of the content that has been certified and accepted after peer review. Copyright and all rights therein are retained by CABI. www.cabi.org/CABReviews

studies that showed positive effects, mainly originated from hardwood charcoal made in a traditional kiln, or from biochars that possessed plant nutrients e.g. high $\mathrm{N}$ i.e. poultry manure biochar. They rightly suggest these results may be skewed toward ring kiln production due to the abundance of biochar made in this way. Other, recent meta-analyses point to an increase in yield from biochar application, suggesting an overall mean increase in crop productivity of $10 \%$ [58]. Others using this approach also found, in general, increased productivity from grass and manure/sewage biochars and high temperature biochars [21]. The studies in these reviews include many from poor soils e.g. particularly those found in the tropics. This positivity was not as apparent in a range of field experiments in the UK showing the effects of biochar in temperate soils [73]. Of the seven field trials composing of 47 treatments, 3 treatments showed increases in yield, most showed no effects and 1 treatment showed a significant yield decrease. Overall, they show that biochar has little effect on crop yield in temperate soils, but imply better targeting may bring some benefits to temperate agriculture [73].

In conclusion, these studies show that biochar has a variety of effects on crop yields but in general can provide some improvement to crop yields, especially to low fertility soils, many studies alluding to increased nutrient availability or increase fertiliser efficiency. What is less apparent within many studies are supporting measures of changes in microbial diversity or metabolic activity, as well as those linked to the potential for some microbes to increase soil nitrogenous gas emissions.

\section{Biochar induced changes in soil microbes, fungi, and $\mathrm{NH}_{3}$ and $\mathrm{N}_{2} \mathrm{O}$}

Relatively little is known about the mechanisms by which biochar affects microbial abundance and diversity, while soil biota studies are severely neglected [40]. The ability of biochar to provide a physical and chemically favourable micro-habitat for soil microbes however, particularly mycorrhizal fungi, may help retain, as well as increase, access to soil and biochar nutrients [72]. This occurs because biochar can provide not only a diverse source of nutrients for these microbes, but also act 
This material has been published in CAB Reviews (2014), Vol. 9 issue 19 pp. 1-19, the only accredited archive of the content that has been certified and accepted after peer review. Copyright and all rights therein are retained by CABI. www.cabi.org/CABReviews

as a primary $\mathrm{C}$ source for respiration [82]. Produced below $500^{\circ} \mathrm{C}$, biochar can contain a labile $\mathrm{C}$ fraction which can stimulate microbial growth and nutrient cycling, however, this can sometimes have negative effects on crop nutrient availability due to $\mathrm{N}$ and $\mathrm{S}$ immobilisation $[41,56,83]$. Biochar may also reduce microbial stress during soil drying events if soil water holding capacity is increased [40].

A number of studies suggest an increase or change in the microbial community of biochar amended soils $[84,85]$ this has been extensively reviewed in Lehmann et al. [40]. The addition of biochar (Eucalyptus oleosa, open pan, no temperature given) increased mycorrihizal fungal colonization and increased grain yield in wheat [86]. Recently, a wood biochar (Malus, $400^{\circ} \mathrm{C}$, slow pyrolysis) was shown to stimulate mycorrhizal fungus colonisation of the roots of Sorghum in the presence of $\mathrm{N}$ over 4 weeks (in a sandy soil) [79]. Crop yield however was significantly reduced and longer-term studies are necessary to test the link between increase mycorrhizal association and increased crop yields. Other studies point to the effects of biochar on microorganisms through releasing or adsorbing microorganism growth-inhibiting or promoting chemicals $[41,42]$.

Many studies fail to measure the change in the rate of microbe induced $\mathrm{NH}_{3}$ or $\mathrm{N}_{2} \mathrm{O}$ release from their soils as a component by which biochar influences soil N. A meta-analysis carried out using 30 studies over the last 6 years showed that overall, biochar reduced soil $\mathrm{N}_{2} \mathrm{O}$ emissions significantly in both the laboratory and field studies [87]. Alterations in emission of $\mathrm{N}_{2} \mathrm{O}$ are important as it is a potent greenhouse gas with agriculture accounting for $58 \%$ of anthropogenic emissions, largely due to the widespread use of synthetic nitrogen fertilisers [87, 88, 89]. Many biochar studies however do not account for any change in soil $\mathrm{N}$ content and its availability caused by this change in soil nitrogenous gas release. A number of recent studies also show an increase in $\mathrm{N}_{2} \mathrm{O}$ emissions $[76,90]$. Others studies show that soil surface volatilisation of $\mathrm{NH}_{3}$ can both decrease and increase postbiochar application $[68,91]$. Many do not then relate this information to the $\mathrm{N}$ availability in the soil. A decrease in nitrogenous gas release may not always mean an increase in soil- $\mathrm{N}$. A measured 
This material has been published in CAB Reviews (2014), Vol. 9 issue 19 pp. 1-19, the only accredited archive of the content that has been certified and accepted after peer review. Copyright and all rights therein are retained by CABI. www.cabi.org/CABReviews

decrease in $\mathrm{NO}_{2}$ release, for example, may not always relate to an increase in the available $\mathrm{NO}_{3}$.

Here the primary reason for the decrease in gas release could be the immobilisation of $\mathrm{NO}_{3}{ }^{-}$within the microbial biomass [38]. The limitations of a number of studies on $\mathrm{N}_{2} \mathrm{O}$ release are they are often conducted using disturbed soil columns in the absence of plants, and are therefore unlikely to represent an accurate measure of field nitrogenous gas release from growing crops. Recently, it has been shown, that plant growth decreased $\mathrm{N}_{2} \mathrm{O}$ emissions due to its requirement for soil available $\mathrm{N}$ and therefore reduced the amount available for denitrification [78].

The application of molecular approaches has assisted in elucidating the underlying mechanism of how biochar influences soil microbes. Studies have been undertaken to identify the abundance and measure the activity of functional marker genes, in the soil nitrogen cycling, in microbial communities [92]. They found that biochar enhanced microbial $\mathrm{N}_{2} \mathrm{O}$ reduction and increased the abundance of $\mathrm{N}_{2}$ fixing organisms. Particularly, biochar increased the abundance and activity of a gene (nosZ) which is believed to enhance microbial reduction of $\mathrm{N}_{2} \mathrm{O}$ to $\mathrm{N}_{2}$. They cautiously suggest that the increased production of $\mathrm{N}_{2}$ from $\mathrm{N}_{2} \mathrm{O}$ may be the underlying mechanism behind the reduction in $\mathrm{N}_{2} \mathrm{O}$ release found in some biochar studies, but there were no measurements of $\mathrm{N}_{2}$ gas release to support their idea [92]. A number of studies mention that $N_{2}$ may be lost as a result of complete denitrification after biochar application and therefore without $\mathrm{N}_{2}$ loss measurements we still lack a full picture of the effect of biochar on soil $\mathrm{N}$ cycling. Although biochar may mainly decrease the greenhouse gas $\mathrm{N}_{2} \mathrm{O}$ emissions from the soils and aid in mitigation of climate change, it may do so through increased $\mathrm{N}_{2}$ gas release and this may in turn, importantly, decrease the availability of $\mathrm{N}$ in the soil for crop growth. A much fuller study of nutrient cycling including $\mathrm{N}_{2}$ and $\mathrm{N}_{2} \mathrm{O}$ gas release is necessary to fully understand biochar effects on $\mathrm{N}$ budgets and greenhouse gas emissions.

\section{Biochar in longer-term field studies}


This material has been published in CAB Reviews (2014), Vol. 9 issue 19 pp. 1-19, the only accredited archive of the content that has been certified and accepted after peer review. Copyright and all rights therein are retained by CABI. www.cabi.org/CABReviews

Field studies from 2010 are described in Table 3 [22,23,31,33,36,37,43,64,73-80]. Studies where feedstock source is not stated and/or pyrolysis method and temperature are not apparent have not been included. There is a tendency for these field studies to use plant derived biochars (PDB) e.g. wood, wheat straw and rice husk biochar whereas the shorter greenhouse studies use a variety of PDBs and ADBs including dry cow manure and waste water sludge. Biochar effects on crop yields in these field studies are generally positive, but not without some exceptions $[64,73]$. These exceptions include no biochar effect and negative effects. Biochar effects on growth in glasshouse studies were mainly positive with few exceptions [76,79]. Again, it was the inclusion of ADB which showed positive effects on crop yield. A 64\% increase in yield of cherry tomatoes (Lycopersicon esculentum) was found using $10 \mathrm{t} \mathrm{ha}^{-1}$ waste water sludge biochar $\left(600^{\circ} \mathrm{C}\right)$ and fertiliser in an Alfisol [93], and an increase in grain yield (Zea mays) of $150 \%$ and $98 \%$ with 15 and $20 \mathrm{t} \mathrm{ha}^{-1}$, respectively applying a CM biochar $\left(500^{\circ} \mathrm{C}\right)$ and fertiliser to a sandy soil.

Many field studies including the ones shown in the Table 3, despite showing mainly increased yields, rarely last longer than a single cropping season $[23,35,94]$. Biochar is known to alter chemically over time due to surface oxidation affecting its CEC, EC and pH [28,44,95-97]. Physical changes occur as labile organics are metabolised by microorganisms or oxides go through dissolution within biochar pores, increasing the internal particle surface area [62,82]. The effect of biochar on crop yields found in the first year of the study therefore may be greater or less than the effect in the second or third year. Biochar studies carried out over three years are rare [73]. Jones et al. [98] is unique in that they studied the effect of biochar over 3 years and also included measurements of the effects of biochar on nutrient cycling They applied wood derived biochar (Fraxinus excelsior, Fagus sylvatica and Quercus robur, $\sim 450^{\circ} \mathrm{C}$, charcoal kiln) to a field maize (Zea mays cv Ohio) crop, and hay grass (Dactylis glomerata) crop on a sandy clay loam and measured changes in soil quality factors, particularly the microbial community, over several years. They showed an increase in grass crop nutritional quality in year two (increased foliar $\mathrm{N}$ concentration) and an increase in biomass production in year three; 
This material has been published in CAB Reviews (2014), Vol. 9 issue 19 pp. 1-19, the only accredited archive of the content that has been certified and accepted after peer review. Copyright and all rights therein are retained by CABI. www.cabi.org/CABReviews

there was no effect on the maize in year one showing that either time ( 2 years and onwards) or a change in crop (maize to grass) induced a biochar effect [98]. There were no changes measured in dissolved organic $\mathrm{C}$ and $\mathrm{N}, \mathrm{NO}_{3}{ }^{-}$or $\mathrm{NH}_{4}{ }^{+}$pool sizes and no long-term effect on $\mathrm{N}$ mineralization, $\mathrm{NH}_{3}$ volatilization, denitrification and $\mathrm{NH}_{4}{ }^{+}$absorption suggesting no significant effect on $\mathrm{N}_{2} \mathrm{O}$ and $\mathrm{NH}_{3}$ emissions. There were however significant increases in bacterial and fungal populations particularly in year two. They emphasised that a number of short-term effects in laboratory studies were not observed in the field, for example, the increased turnover of field microbial mass was not apparent in the laboratory ${ }^{14} \mathrm{C}$ labelled mineralisation studies [98]. This is perhaps not surprisingly, when plants are absent and there are probable changes in soil physical structure and chemical attributes. The likely loss of soil structure at the macro and micro-scale (rhizosphere) when sampling can often influence soil function.

In general, but with exceptions [98], there are few longer-term studies that measure nutrient concentrations, $\mathrm{NH}_{3}$ and $\mathrm{N}_{2} \mathrm{O}$ release and yield in soils and even fewer in temperate soils, and hardly any have measured the effect of biochar on $\mathrm{N}_{2}$ gas release. The complexity of nutrient cycling and biochar in soils, including the addition of $\mathrm{N}$ from biochar, reduction in leaching, the change of $\mathrm{NH}_{3}{ }^{-}$, $\mathrm{N}_{2} \mathrm{O}$ and $\mathrm{N}_{2}$ soil release and the effects of biochar induced changes in microbe $\mathrm{N}$ cycling need to considered in detailed in-situ studies.

\section{BIOCHAR AS AN IMPROVER OF SOIL WATER AVAILABILITY}

\section{The evidence for Terra preta soils having increased water holding capacity}

Increasing SOM content improves soil moisture retention and crop water availability which is a key factor in determining agricultural productivity [99]. It is therefore not surprising that the original Amazonian Terra preta soil patches containing high SOM have higher moisture contents relative to non-Terra preta neighbouring soils [100-103] and quoted within from Hartt 1885. A number of non- 
This material has been published in CAB Reviews (2014), Vol. 9 issue 19 pp. 1-19, the only accredited archive of the content that has been certified and accepted after peer review. Copyright and all rights therein are retained by CABI. www.cabi.org/CABReviews

peer reviewed studies, in Portuguese, describe many Terra preta soil patches where soil 'moisture retention' is suggested as an important plant growth determinant (see $[1,103,104])$. A comparison between a Terra preta patch and the local native Ferralsols showed a 15\% increase topsoil horizon 'field capacity', from which they conclude growth on Terra preta was in part due to an improved water supply [103], as may be the case elsewhere [105]. However, recent texts on Terra preta and biochar generally provide little critical data to support the notion of Terra preta induces changes in soil water content $[100,106,107]$. Speculation implies that it is through increases in SOM that improvements in soil particulate aggregation which improves porosity and therefore crop water availability, particularly in soils with coarse structures $[100,108]$. This speculative approach can have limited supporting evidence, which is given credibility, e.g. see the mention in the abstract of [109] despite only a single study [55] cited in the body of the review. The effects of changes in soil structure on crop water availability can however only be fully determined from measurements of soil 'matric potential' (soil matric potential $\psi_{\mathrm{m}}$ ); as this measures the energy required to remove water from within (absorption) and adhering (adsorption) to soil particles and therefore the ability of the plant to capture it. It is therefore challenging from these predominantly descriptive reports to conclude that Terra preta influences plant growth by improving the soil-plant water balance. If biochar incorporation alters soil structure then changes in soil water holding capacity and crop water availability can be influenced, but this can only be effectively determined from measurements of $\psi_{\mathrm{m}}$.

\section{The evidence for biochar increasing soil water availability}

Despite the lack of appropriate data to support the notion that increased plant growth on Terra preta soil patches was due to improvements in plant-soil water relations, this does not mean that the pyrolysed organic carbon incorporated into soil, as biochar, will not increase its water holding capacity [58.110]. We are, however, equally interested in knowing whether the properties, which may explain Amazonian Terra preta increases in plant productivity, translate into agricultural benefits for soils and climates outside the tropics [8]. From its physical nature, charcoal, a type of 
This material has been published in CAB Reviews (2014), Vol. 9 issue 19 pp. 1-19, the only accredited archive of the content that has been certified and accepted after peer review. Copyright and all rights therein are retained by CABI. www.cabi.org/CABReviews

biochar, is known to be porous with an ability for chemical adsorption and the retention of gases, in proportion to its pore geometry and size [111-113], but less is known about its direct water holding capacity [114]. Evidence of the measured impact of charcoal incorporation into temperate soils is not extensive but, work with North American forest soils shows that charcoal soil promotes 'available moisture' (increased by 18\%) and reduces evaporation [115]. These differences were only detectable in sandy soils, and when incorporation rates were high ( $45 \%$ by volume, $\left.\sim 70 \mathrm{t} \mathrm{ha}{ }^{-1}\right)$. Incorporation rates, at this level, are unlikely to be achievable for many reasons, beyond the simple availability of sufficient feedstock to produce the biochar. Chan et al. [30] suggest that biochar improves soil water holding capacity with applications in excess of $50 \mathrm{t} \mathrm{ha} \mathrm{a}^{-1}$. They however only provide measurements made at field capacity, so despite a possible increase in plant water availability we cannot be sure that soil-plant moisture conservation is enhanced and likely to improve crop performance, particularly under water restricted conditions. A number of studies similar in nature to that of Chan et al. [30] imply biochar improved soil water status. Conversely, few studies show beneficial biochar responses in the absence of suggestions that crop and soil water relations have improved; there are exceptions [116], with positive biochar effects but no change in soil water status. One study suggests that water use efficiency is increased with biochar application, but here the improvement was not due to less water being used just an increased yield in the absence of a direct link with water use or its availability [80]. Similarly, work reported with dry land wheat strongly suggests that yield benefits result from improved crop water uptake; however neither soil water, nor crop water uptake data are presented [72]. A study involving sugarcane bagasse biochar ( $3 \%$ by weight) using lysimeter plots suggests available soil moisture increased due to the presence of biochar [117]. Initial differences in the moisture content of treated soils, prior to crop growth, between the experimental plots and the controls were large and varied from $20 \%$ to $60 \%$. There appeared to be some form of a relationship between the rainfall and irrigation inputs and the fluctuations in soil water, but this was only apparent in the one of the biochar treatments and not in the other, or in the controls. Subsequent, measurements of available soil moisture, during 
This material has been published in CAB Reviews (2014), Vol. 9 issue 19 pp. 1-19, the only accredited archive of the content that has been certified and accepted after peer review. Copyright and all rights therein are retained by CABI. www.cabi.org/CABReviews

crop growth, showed moisture differences which did not exceed $10 \%$. In an attempt to determine the impact of biochar (application rates of 100 to $200 \mathrm{t} \mathrm{ha}^{-1}$ ) on Quinoa physiology at different soil 'water holding capacities' (WHC) plants were grown at $60 \%$ and $20 \%$ WHC [37]. What we do not know about these experiments is the extent to which the low WHC treatments induced a decline in soil or plant water potentials. We also know nothing about the direct effects of these variables on key physiological processes (e.g. leaf growth, transpiration) and how they will have adjusted to null the treatment differences in crop water management when applied using a constant field capacity regime determined by gravimetric analysis.

More recent work also suggests the notion that increased soil available water, due to biochar incorporation, is restricted to sandy soils $[48,80,118,119]$. The use of cored soils of different mineralogy, and the addition of biochar at $7 \mathrm{t} \mathrm{ha}^{-1}$, showed incubation time, which including a series of wetting and drying cycles, increased soil available water [120]. Equally important to this conclusion was their attempt to quantify water availability by measuring soil moisture content at a range of matric potentials. From this these authors were able to express notions about the effectiveness with which plants can absorb water from soils amended with biochar. Some soils show that their water holding capacity, against gravity, and therefore presumably available for crop growth, was increased with $3 \%(\mathrm{w} / \mathrm{w})$ biochar incorporation [62]. They attributed this increase to the higher total porosity enabling more water to be retained in biochar treated soil. Using gravimetric soil moisture content data also has limited usefulness in trying to quantify available water and the assumptions would be large if we derive calculated soil water storage to determine biochar benefits. Biochar research urgently needs greater attention given to study of its potential benefits to crop growth, through changes in soil water availability. The work of Baronti et al. [121] is rare in that it provides links between crop physiological behaviour and the appropriate soil and plant water analyses and methodology to do this. 
This material has been published in CAB Reviews (2014), Vol. 9 issue 19 pp. 1-19, the only accredited archive of the content that has been certified and accepted after peer review. Copyright and all rights therein are retained by CABI. www.cabi.org/CABReviews

There are a number of studies that rightly emphasise the less direct importance of soil water status in contributing to agricultural performance. Biochar functional groupings change initially after soil exposure to water (biochar oxidation) and this can be linked to an increase in CEC [79]. It is also suggested that biochar addition can affect soil physical properties by absorbing excessive soil moisture [122]. By so doing this increased soil porosity and aeration can influence $\mathrm{N}_{2} \mathrm{O}$ generation and diffusion. Changes in aeration and oxygen content influence both nitrifiers and denitrifiers [87]. Denitrification being dominant above $70 \%$ water filled pore space [123]. Several studies link both the positive and negative functional importance of soil microbial activity, particularly through soil C losses, respiration rates, denitrification and the release of $\mathrm{N}_{2} \mathrm{O}[42,74,78,124-127]$. Soil microbial status and function will likely change in response to environmental variables like soil water content which influences oxygen tensions and the capacity of the soil micro-organisms to oxidise SOM, as well as those linked to nutrient availability, mineralisation and leaching [103,108,129-131]. Many of these studies equally suffer from data which is limited to describing WHC. Given the conclusion that the evidence for biochar enhancing in soil water availability is not well supported there may be opportunities to develop appropriate biochar characteristics, providing they translate into physical changes in for example, soil hydrology and field capacity, to produce smart biochars [132]. Pyrolysis temperature and feedstock source appear good candidates to alter these characteristics, e.g. hydrophobicity $[114,125,133-136]$. This avenue of evaluation is again limited by the consideration of only field capacity measurements.

\section{Implications of variability in biochar production and smart biochar}

We started this article by asking the question; can we show that biochar is an improver of nutrient and soil water availability? This has been a challenging question to answer and one of the reasons for this is that biochar is an umberella term for many different types of pyrolysed organic material. To provide some degree of clarity in this variability, it has been useful to separate biochar into those derived from plant material and those made from animal products; i.e. plant derived biochar (PDB) 
This material has been published in CAB Reviews (2014), Vol. 9 issue 19 pp. 1-19, the only accredited archive of the content that has been certified and accepted after peer review. Copyright and all rights therein are retained by CABI. www.cabi.org/CABReviews

and animal derived biochar (ADB). We need to remember however that there is not only variation between feedstocks, but also variation within feedstocks. For example, there is feedstock variability between woody species in regard to cell density and its chemical composition and there may also be variation in nutrient concentration for ADB manure feedstock depending on the animal's feed (see Table $4[26,43,46,53])$. Also, the production methodology, the post-production procedures, the quantity and method of incorporation into soil all have an impact on variability of biochar function $[19,20,25,28,34,72]$ (see Figure $1[22,23,31,33,36,37,43,64,73-80]$ ). Soil type and climate also influences biochar function, and may have a particularly important role in how biochar changes physically and chemically over time [62,82]. The diagrammatic flow chart in Figure 1 uses a simple linear flow model without consideration of interactive effects between some of these factors, which will undoubtedly make understanding biochar function more complex. This variability is however not just a hindrance in our attempts to understand how it functions, it provide us with the potential to develop biochars designed for a wide range of specific purposes ('Smart biochars'). In a number of respects the idea of smart biochars aligns with the notion that biochar usage and production are not assigned to multiple benefits but functional trade-offs have to be considered. This approach is described in detail by Jeffery et al. [26]. It is important that biochar is created for a purpose, selecting the particular variables to produce a biochar with a chosen function $[45,48]$. For example, a biochar produced from wood at $600^{\circ} \mathrm{C}$ will retain some nutrients which are available, such as $\mathrm{K}$, while having a high $\% \mathrm{C}$ content, low $\%$ of labile $\mathrm{C}$ and a high surface area. It may also have the ability to decrease leaching of nitrates, increase in CEC over time and provide a habitat for microorganisms, without impacting greatly on immobilisation of nutrients. It may be used as a way of increasing the efficiency of fertiliser soil applications or to adsorb ammonia from animal waste and enable $\mathrm{NH}_{3}$ recycling into cropping systems. This type of biochar has been found to be useful as a soil amendment and in $\mathrm{C}$ sequestration due to its high recalcitrant nature. A manure based biochar on the other hand may be produced primarily as a means of dealing with a waste issue e.g. reduction in volume of waste and transport costs [43], and, having a high available $\mathrm{N}$ and $\mathrm{P}$ content as well as 
This material has been published in CAB Reviews (2014), Vol. 9 issue 19 pp. 1-19, the only accredited archive of the content that has been certified and accepted after peer review. Copyright and all rights therein are retained by CABI. www.cabi.org/CABReviews

micronutrients, may be used as a 'slow release fertiliser'. As the $C$ content is lower and the labile fraction is higher, in these biochars, they breakdown more easily and have a greater short-term impact on microbial communities. These ADB therefore have limited long-term $C$ sequestration capacity. It is important to know what problem biochar application is trying to address, for example, increasing soil fertility (increase soil pH, increasing nutrients, decreasing leaching) and/or promoting C sequestration and then target the biochar to the function necessary.

\section{Conclusions}

Having the capacity to predict and produce biochars that induce beneficial changes in crop nutrition and soil water availability will be particularly important in meeting the demand for increased food production, whilst using resources more efficiently. Increasing nutrient use efficiency will have economic and environmental benefits, while improvements in the soils water holding capacity will help buffer soils against degradation and the impacts of climate change. This review has given details of biochar research that show a varying but generally small and positive effect of biochar application on soil nutrient concentrations and availability. Many, however, do not fully investigate the underlying mechanisms, the effect of nitrogenous gas release $\left(\mathrm{NH}_{3}, \mathrm{~N}_{2} \mathrm{O}\right.$ and $\left.\mathrm{N}_{2}\right)$ and the influence of the change in microbial diversity and activity on nutrient cycling. Some field trails show increased yields but are much too short in length to give a full picture of how biochar will interact with the soil and effect crop yields in the longer-term.

Attention has also been given to the importance of biochar in improving soil water holding capacity and crop available water. In general many of these studies are limited in how they assess the effect of biochar on the amount of water available to plants and therefore we have a limited knowledge of whether there are actual benefits to biochar use in this regard. Importantly, biochar studies and the biochar industry may have been held back by variation in its function in different soils and climates; 
This material has been published in CAB Reviews (2014), Vol. 9 issue 19 pp. 1-19, the only accredited archive of the content that has been certified and accepted after peer review. Copyright and all rights therein are retained by CABI. www.cabi.org/CABReviews

this has much to do with the variation in feedstock, production method and means of application to soil (Figure 1). It has therefore been useful to separate biochar into PDB and ADB. The understanding of these factors should be improved so we can design biochars with predictable functions. The main aim of the application of biochar to a soil needs to be clear beforehand with regards to the soil $\mathrm{pH}$ changes required, the nutrient leaching issues, availability of water and drought problems and whether we require nutrient release from the biochar or if we are adding nutrients to it. Biochar that is created as a way of dealing with a waste issue or created to sequester $C$ or that is a bioenergy by product will have different considerations. In all cases, the characteristics of the biochar need to be thoroughly designed to fulfil its predetermined function if it is to become an improver of soil nutrient and water availability.

\section{Acknowledgements}

HS was supported by funds provided from the University of Greenwich's via the Vice Chancellor's studentship award scheme.

\section{References}

1. Kern DC, D'Aquino G, Rodrigues ET, Frazao FJL, Sombroek W, Myers TP, et al. Distribution of Amazonian dark earths in the Brazilian Amazon. In: Lehmann J, Kern DC, Glaser B, Woods WI, editors. Amazonian Dark Earths Origin Properties Management. Dordrecht: Kluwer Academic Publishers; 2003. p. 51-75.

2. Lehmann J, Kern D, German L, McCann J, Martins GC, Moreira L. Soil fertility and production potential. In: Lehmann J, Kern DC, Glaser B, Woods WI editors. Amazonian Dark Earths: Origin, Properties, Management. Dorcrecht: Kluwer Academic Publishers; 2003b p. 105-124.

3. Lehmann J, Rondon MA. Bio-char soil management on highly weathered soil in the humid tropics. In: Uphoff N, editor. Biological approaches to sustainable soil systems. Boca Raton: CRC; 2005. p. 517-530.

4. Forbes MS, Raison RJ, Skjemstad JO. Formation, transformation and transport of black carbon (charcoal) in terrestrial and aquatic ecosystems. Science of the Total Environment 2006;370:190-206. 
This material has been published in CAB Reviews (2014), Vol. 9 issue 19 pp. 1-19, the only accredited archive of the content that has been certified and accepted after peer review. Copyright and all rights therein are retained by CABI. www.cabi.org/CABReviews

5. Steiner C. Soil charcoal amendments maintain soil fertility and establish a carbon sink research and prospects. In: Liu T-X, editor. Soil Ecology and Research Developments. Nova Publishers; 2007. p. 1-6.

6. Lehmann J, Grant J, Rondon M. Biochar sequestration in terrestrial ecosystems - a review. Mitigation, Adaptation and Strategies for Global Change 2006;11:403-427.

7. Blackwell P, Riethmuller G, Collins M. Biochar application for soil. In: Lehmann J and Joseph S, editors. Biochar for Environmental Management Science and Technology. London: Earthscan; 2009. p. 207-226.

8. Atkinson CJ, Fitzgerald JD, Hipps NA. Potential mechanisms for achieving agricultural benefits from biochar application to temperate soils: a review. Plant and Soil 2010;337:1-18.

9. Woolf D, Amonette JE, Street-Perrott FA, Lehmann J, Joseph S. Sustainable biochar to mitigate global climate change. Nature Communications 2010;1:56. DOI: 10.1038/ncomms1053.

10. Glaser B, Haumaier L, Guggenberger G, Zech W. The 'Terra Preta' phenomenon: a model for sustainable agriculture in the humid tropics. Naturwissenschaften 2001;88:37-41.

11. Glaser B, Lehmann J, Zech W. Ameliorating physical and chemical properties of highly weathered soils in the tropics with charcoal - a review. Biology and Fertility of Soils 2002;35:219-230.

12. Lehmann J, da Silva Jr JP, Steiner C, Nehls T, Zech W, Glaser B. Nutrient availability and leaching in an archaeological Anthrosol and Ferralsol of the Central Amazon basin: fertilizer, manure and charcoal amendments. Plant and Soil 2003;249:343-357.

13. Lehmann J, Kern DC, Glaser B, Woods WI. Amazonian Dark Earths Origin Properties Management. Dordrecht: Kluwer Academic Publishers; 2003.

14. DeLuca TH, MacKenzie MD, Gundale MJ. Biochar effects on soil nutrient transformation. In: Lehmann J, Joseph S. editors. Biochar for Environmental Management Science and Technology. London: Earthscan; 2009. p. 251-280.

15. Steiner C, Das KC, Garcia M, Forester B, Zech W. Charcoal and smoke extract stimulate the soil microbial community in a highly weathered xanthic Ferralsol. Pedobiologia 2008;51:359-366.

16. Woolf $D$, Lehmann J, Modelling the long-term response to positive and negative priming of soil organic carbon by black carbon. Biogeochemistry 2012;111;83-95.

17. Novak, JM, Busscher WJ, Watts DW, Amonette JE, Ippolito JA et al. Biochars impact on soilmoisture storage in an Ultisol and two Aridisols. Soil Science 2010;177:310-320.

18. Nelson N, Agudelo S, Yuan W, Gan Y. Nitrogen and phosphorus availability in biochar amended soils. Soil Science 2011;176:218-226.

19. Spokas KA, Cantrell KB, Novak JM, Archer DW, Ippolito JA, Collins HP et al. Biochar: A synthesis of its agronomic impact beyond carbon sequestration. Journal of Environmental Quality 2012;41:973-987. 
This material has been published in CAB Reviews (2014), Vol. 9 issue 19 pp. 1-19, the only accredited archive of the content that has been certified and accepted after peer review. Copyright and all rights therein are retained by CABI. www.cabi.org/CABReviews

20. Angst T, Sohi S. Establishing release dynamics for plant nutrients from biochar. Global Change Biology and Bioenergy 2012;5:221-226.

21. Biederman LA, Harpole SW. Biochar and its effects on plant productivity and nutrient cycling: a meta-analysis. Global Change Biology and Bioenergy 2013;5:202-214.

22. Milla OV, Rivera EB, Huang W-J, Chien C-C, Wang Y-M. Agronomic properties and characterization of rice husk and wood biochars and their effect on the growth of water spinach in a field test. Journal of Soil Science and Plant Nutrition. 2013;13:251-266.

23. Major J, Lehmann J, Rondon M, Goodale C. Fate of soil- applied black carbon: Downward migration, leaching and soil respiration. Global Change Biology 2010;16:1366-1379.

24. Sohi SP, Krull E, Lopez-Capel E, Bol R. A review of biochar and its use and function in soil. Advances in Agronomy, 2010;105:47-82.

25. Brewer CE, Unger R, Schmidt- Rohr K, Brown RC. Criteria to select biochars for field based studies based on biochar chemical properties Bioenergy Research 2011;4:312-323.

26. Jeffery S, Bezemer TM, Cornelissen G, Kuyper TW, Lehmann J, Mommer L, Sohi SP, Van de Voorde TFJ, Wardle DA, Van Groenigen JW. The way forward in biochar research: targeting trade-offs between the potential wins. Bioenergy 2013; doi: 10.1111/gcbb.12132.

27. Delgardo-Baquerizo M, Maestre FT, Gallardo A, Bowker MA, Wallenstein MD, Quero JL, et al. Decoupling of soil nutrient cycles as a function of aridity in global drylands. Nature 2013;502:672-675.

28. Gaskin JW, Steiner C, Harris K, Das KC, Bibens B. Effect of low-temperature pyrolysis conditions on biochar for agricultural use. American Society of Agricultural and Biological Engineers 2008;51:2061-9.

29. de la Rosa JM, Knicker $\mathrm{H}$. Bioavailability of $\mathrm{N}$ released from $\mathrm{N}$-rich pyrogenic organic matter: An incubation study. Soil Biology and Biochemistry 2011;43:2368-2373.

30. Chan KY, Van Zwieten L, Meszaros I, Downie A, Joseph S. Agronomic values of green waste biochar as a soil amendment. Australian Journal of Soil Research 2007;45:629-634.

31. van Zwieten L, Kimber S, Downie A, Morris S, Petty S. A glasshouse study on the interaction of low mineral ash biochar with nitrogen in a sandy soil. Soil Research 2010;48:569-576.

32. Hua L, Wu WX, Liu YX, McBride M, Chen YX. Reduction of nitrogen loss and Cu and Zn mobility during sludge composting with bamboo charcoal amendment. Environmental Science and Pollution Research 2009;16:1-9.

33. van Zweiten L, Kimber S, Morris S, Chan KY, Downie A, Rust J et al. Effects of biochar from slow pyrolysis of paper mill waste on agronomic performance and soil fertility. Soil Research 2010;327:235-246.

34. Ding Y, Liu YX, Wu WX, Shi DZ, Yang M, Zhong ZK. Evaluation of biochar effects on nitrogen retention and leaching in multi-layered soil columns. Water, Air and Soil Pollution 2010;213:47-55. 
This material has been published in CAB Reviews (2014), Vol. 9 issue 19 pp. 1-19, the only accredited archive of the content that has been certified and accepted after peer review. Copyright and all rights therein are retained by CABI. www.cabi.org/CABReviews

35. Zhang A, Cuia L, Pan G, Li L, Hussain Q, Zhang X, Zheng J. et al. Effect of biochar amendment on yield and methane and nitrous oxide emissions from a rice paddy from Tai Lake plain, China. Agriculture, Ecosystems and Environment 2010;139:469-475.

36. Zhang A, Bian R, Pan G, Cuia L, Hussain Q, Li L. et al. Effects of biochar amendment on soil quality, crop yield and greenhouse gas emission in a Chinese rice paddy: A field study of 2 consecutive rice growing cycles. Field Crops Research 2012;127:153-160.

37. Kammann Cl, Linsel S, Gobling JW, Koyro H-W. Influence of biochar on drought tolerance of Chenopodium quinoa Willd and on soil-plant relations. Plant and Soil 2011;345:195-210.

38. Case SDC, McNamara NP, Reay DS, Whitaker J. The effect of biochar addition on $\mathrm{N}_{2} \mathrm{O}$ and $\mathrm{CO}_{2}$ emissions form a sandy loam soil- The role of soil aeration. Soil Biology and Biochemistry 2012;51:125-134.

39. van Zwieten L, Kimber S, Morris S, Downie A, Berger E, Rust J et al. Influence of biochars on flux of $\mathrm{N}_{2} \mathrm{O}$ and $\mathrm{CO}_{2}$ from Ferrosol. Soil Research 2010;48:555-568.

40. Lehmann J, Rillig MC, Theis J, Masiello A, Hockaday W et al. Biochar effects on soil biota- A review. Soil Biology and Biochemistry 2011;43:1812-1836.

41. Deenik JL, Mc Clellan T, Uehara G, Antal MJ, Cambell S. Charcoal Volatile matte content influences plant growth and soil nitrogen transformation. Soil Science Society of America 2010;74:1259-1270.

42. Spokas KA, Baker JM, Reicoshy DC. Ethylene: potential key for biochar amendment impacts. Plant and Soil 2010;333:443-452.

43. Hossain MK, Strezov V, Chan KY, Ziolkowski A, Nelson PF. Influence of pyrolysis temperature on production and nutrient properties of wastewater sludge biochar. Journal of Environmental Management, 2011;92:223-228.

44. Singh B, Singh BP, Cowie AL. Characterisation and evaluation of biochars for their application as a soil amendment. Soil Research 2010a;48:516-525.

45. Novak JM, Cantrell KB, Watts DW, Busscher WJ, Johnson, MG. Designing relevant biochars as soil amendments using lignocellulosic-based and manure-based feedstocks. Journal of Soils and Sediments 2013a;00:1-14.

46. Clough TJ, Condron LM, Kammann C, Muller C. A review of biochar and soil nitrogen dynamics. Agronomy 2013;3:275-293.

47. Ippolito JA, Laird DA, Busscher WJ. Environmental benefits of biochar. Journal of environmental quality 2012;41:967-972.

48. Novak JM, Lima I, Xing B. Gaskin JW, Steiner C, Das KC, et al. Characterization of designer biochar produced at different temperatures and their effects on a loamy sand. Annals of Environmental Science 2009;3:195-206. 
This material has been published in CAB Reviews (2014), Vol. 9 issue 19 pp. 1-19, the only accredited archive of the content that has been certified and accepted after peer review. Copyright and all rights therein are retained by CABI. www.cabi.org/CABReviews

49. Sjostrom E. Wood chemistry: Fundamentals and applications. 2nd ed. San Diego, US: Academic press; 1993. In: Lehmann J, Joseph S. editors. Biochar for Environmental Management Science and Technology. London: Earthscan; 2009 p. 16.

50. Knoepp JD, DeBano LF, Neary DG. Soil chemistry. Wildland fire in ecosystems. Effects of fire on soil and water. General Technical Report. RMRS-GTR; 2005;42:53-71.

51. Chan KY, Xu Z. Biochar: nutrient properties and their enhancement. In: Lehmann J and Joseph $S$, editors. Biochar for Environmental Management Science and Technology. London: Earthscan; 2009. p. 67-84

52. Kloss S, Zehetner F, Dellantonio A, Hamid R, Ottner F, Liedtke V et al. Characterization of slow pyrolysis biochars: effects of feedstocks and pyrolysis temperature on biochar properties. Journal of Environmental Quality 2012;41:990-1000.

53. Mašek $O$, Brownsort $P$, Cross $A$, Sohi S. Influence of production conditions on the yield and environmental stability of biochar. Fuel 2013;103:151-155.

54. Gundale MJ, DeLuca TH. Temperature and substrate influence the chemical properties of charcoal in the ponderosa pine/Douglas-fir ecosystems. Forest Ecology and Management 2006;231:86-93.

55. Asai H, Samson BK, Stephan HM Songyikhangsuthor K, Homma K, Kiyono Y, Inoue Y, Shiraiwa T, Horie T. Biochar amendment techniques for upland rice reproduction in Northern Laos: 1 Soil physical properties, leaf SPAD and grain yield. Field Crop Research 2009;111:81-84.

56. Ippolito JA, Novak JM, Busscher WJ, Ahmedna M, Rehrah D, Watts DW. Switchgrass biochar affects two ardisols. Journal of Environmental Quality 2012;41:1123-1130

57. Schouten S, van Groenigen JW, Oenema O, Cayuela ML. Bioenergy from cattle manure? Implications of anaerobic digestion and subsequent pyrolysis for carbon and nitrogen dynamics in soil. GCB Bioenergy 2012;4:751-760.

58. Jeffery S, Verheijen FGA, van der Velde M, Bastos AC. A quantitative review of the effects of biochar application to soils on crop productivity using meta-analysis. Agriculture, Ecosystems and Environment 2011;144:175-187.

59. Knicker $\mathrm{H}$, Skjemstad JO. Nature of organic carbon and nitrogen in physically protected organic matter of some Australian soils as revealed by solid-state ${ }^{13} \mathrm{C}$ and ${ }^{15} \mathrm{~N}$ NMR spectroscopy. Australian Journal of Soil Research 2000;38:113-127.

60. Wang T, Camps Arbestain M, Hedley M, Bishop P. Chemical and bioassay characterisation of nitrogen availability in biochar produced from dairy manure and biosolids. Organic Geochemistry 2012;51:45-54.

61. Yamato M, Okimori Y, Wibowo IF, Anshori S, Ogawa, M. Effects of the application of charred bark of Acacia mangium on the yield of maize, cowpea and peanut, and soil chemical properties in South Sumatra, Indonesia. Soil Science and Plant Nutrition 2006;52:489-495. 
This material has been published in CAB Reviews (2014), Vol. 9 issue 19 pp. 1-19, the only accredited archive of the content that has been certified and accepted after peer review. Copyright and all rights therein are retained by $C A B I$. www.cabi.org/CABReviews

62. Basso AS, Miguez FE, Laird DA, Horton R, Westgate M. Assessing potential of biochar for increasing water holding capacity of sandy soils. Global Change Biology Bioenergy 2013;5:132143.

63. Yao $\mathrm{Y}$, Gao B, Zhang $\mathrm{M}$, Inyang $\mathrm{M}$, Zimmerman AR. Effect of biochar amendment on sorption and leaching of nitrate, ammonium, and phosphate in a sandy soil. Chemosphere 2012;89:1467-1471.

64. Lentz RD, Ippolito JA. Biochar and manure affect calcareous soil and corn silage nutrient concentration and uptake. Journal of Environmental Quality 2012;41:1033-1043.

65. Kameyama K, Miyamoto T, Shiono T, Shinogi $\mathrm{Y}$. Influence of sugarcane bagasse-derived biochar application on nitrate leaching in calcaric dark red soil. Journal of Environmental Quality, 2012;41:1131-1137.

66. Singh BP, Hatton BJ, Singh B, Cowie AL, Kathuria A. Influence of biochars on nitrous oxide emission and nitrogen leaching from two contrasting soils. Journal of Environmental Quality 2010;39:1224-1235.

67. Laird D, Fleming P, Wang B, Horton R, Karlen D. Biochar impact on nutrient leaching from a Midwestern agricultural soil. Geoderma 2010;158:436-442.

68. Schomberg HH, Gaskin JK, Harris, KC, Dasa KC, Novak JM, Busscher DW et al. Influence of biochar on nitrogen fractions in a Coastal Plain Soil. Journal of Environmental Quality 2012;41:1087-1095.

69. Sarkhot DV, Berhe AA, Ghezzehei TA. Impact of biochar enriched with dairy manure effluent on carbon and nitrogen dynamics. Journal of Environmental Quality 2012;41:1107-1114.

70. Taghizadeh-Toosi A, Clough TJ, Sherlock RR, Condron LM. Biochar adsorbed ammonia is bioavailable Plant and Soil 2012;350:57-69.

71. Taghizadeh-Toosi A, Clough TJ, Sherlock RR, Condron LM. A wood based low-temperature biochar captures NH3-N generated from ruminant urine- $\mathrm{N}$, retaining its bioavailability. Plant and Soil 2012;353:73-84.

72. Blackwell P, Krull E, Butler G, Herbert A, Solaiman Z. Effect of banded biochar on dryland wheat production and fertiliser use in south-western Australia: an agronomic and economic perspective. Australian Journal of Soil Research 2010;48:531-545.

73. Hammond J, Shackley S, Prendergast-Miller M, Cook J, Buckingham S, Pappa VA. Biochar field testing in the UK: outcomes and implications for use. Carbon Management 2013;4:159-170.

74. Jones DL, Rousk J, Edwards-Jones G, DeLuca TH, Murphy DV. Biochar-mediated changes in soil quality and plant growth in a three year field trial. Soil Biology and Biochemistry 2012;45:113124.

75. Zhang A, Liu Y, Pan G, Hussain Q, Li L, Zheng J, Zhang X. Effect of biochar amendment on maize yield and greenhouse gas emissions from a soil organic carbon poor calcareous loamy soil from Central China Plain. Plant and Soil 2012;351:263-275. 
This material has been published in CAB Reviews (2014), Vol. 9 issue 19 pp. 1-19, the only accredited archive of the content that has been certified and accepted after peer review. Copyright and all rights therein are retained by $C A B I$. www.cabi.org/CABReviews

76. Xie Z, Xu Y, Liu G, Liu Q, Zhu J, Tu C et al. Impact of biochar application on nitrogen nutrition of rice, greenhouse emissions and soil organic carbon dynamics in two paddy soils of China. Plant and Soil 2013;370:527-540.

77. Noguera D, Barot S, Laossi KR, Cardoso J, Lavelle P, Cruz de Carvalho MH. Biochar but not earthworms enhances rice growth through increased protein turnover. Soil Biology and Biochemistry 2012;52:13-20.

78. Saaranio $\mathrm{S}$, Heimonen $\mathrm{K}$, Kettunen $\mathrm{R}$. Biochar addition indirectly affects $\mathrm{N}_{2} \mathrm{O}$ emissions via soil moisture and plant $\mathrm{N}$ uptake. Soil Biology and Biochemistry 2013;58:99-106.

79. LeCroy C, Masiello CA, Rudgers JA, Hockaday WC, Silberg J. Nitrogen, biochar, and mycorrhizae: alteration of the symbiosis and oxidation of the char surface. Soil Biology and Biochemistry 2013;58:248-254.

80. Uzoma KC, Inoue M, Andry H, Fujimaki H, Zahoor A, Nishihara E. Effect of cow manure biochar on maize productivity under sandy soil condition. Soil Use and Management 2011;27:205212.

81. Zimmerman AR, Gao B, Ahn MY. Positive and negative carbon mineralization priming effects among a variety of biochar-amended soils. Soil Biology and Biochemistry 2011;43:1169-1179.

82. Thies JE, Rillig MC. Characteristics of biochar: Biological properties. In: Lehmann, J, Joseph S editors. Biochar for Environmental Management: Science and Technology. United Kingdom. Earthscan; 2009. p. 85-105.

83. Graber ER, Harel YM, Kolton M, Cytryn E, Silber A, David DR, Tsechansky L, Borenshtein M, Elad Y. Biochar impact on development and productivity of pepper and tomato grown in fertigated soilless media. Plant Soil 2010;337:481-496.

84. Grossmann JM, O Niel BE, Tsai SM, Liang B, Neves E, Lehmann J et al. Amazonian anthrosols support similar microbial communities that differ distinctly for those extant in adjacent, unmodified soils of the same mineralogy. Microbial Ecology 2010;60:192-205.

85. Liang B, Lehmann J, Sohi S, Theis JE, O Niel B, Trujillo L et al. Black carbon affects the cycling of non-black carbon in the soil. Organic Geochemistry 2010;41:206-213.

86. Solaiman ZM, Blackwell P, Abbott LK, Storer P. Direct and residual effect of biochar application on mycorrhizal root colonisation, growth, and nutrition of wheat. Australian Journal of Soil Research 2010;48:546-554.

87. Cayuela ML, van Zwieten L, Singh BP, Jeffery S, Roig A, Sanchez-Mondero MA. Biochar's role in mitigating soil nitrous oxide emissions: A review and meta-analysis. Agriculture, Ecosystems and Environment. 2013:

88. Forster $\mathrm{P}$, Ramaswamy $\mathrm{V}$, Artaxo $\mathrm{P}$, Bernsten $\mathrm{T}$, Betts $\mathrm{R}$, Fahey DW et al. Changes in atmospheric constituents and in radiative forcing In: Solomon S, Qin D, Manning M, Chen Z, Marquis KB, Averyt $M$ et al. editors. Climate change 2007: The physical science basis. Contributions of working group 1 to the fourth assessment report of the Intergovernmental Panel on climate change. Cambridge University Press, Cambridge, UK. 
This material has been published in CAB Reviews (2014), Vol. 9 issue 19 pp. 1-19, the only accredited archive of the content that has been certified and accepted after peer review. Copyright and all rights therein are retained by $C A B I$. www.cabi.org/CABReviews

89. Solomon S, Qin D, Manning M, Chen Z, Marquis KB, Averyt M et al editors. Climate change 2007: The physical science basis. Contributions of working group 1 to the fourth assessment report of the Intergovernmental Panel on climate change. Cambridge University Press, Cambridge, UK.

90. Troy SM, Lawlor PG, O'Flynn CJ, Healy MG. Impact of biochar addition to soil on greenhouse gas emissions following pig manure application. Soil Biology and Biochemistry 2013;60:173181.

91. Steiner C, Das KC, Melear N, Lakly, D. Reducing nitrogen loss during poultry litter composting using biochar. Journal of Environmental Quality 2010; 39:1236-1242.

92. Harter J, Krause HM, Schuettler S, Ruser R, Fromme M, Scholten T et al. Linking $\mathrm{N}_{2} \mathrm{O}$ emissions from biochar-amended soil to the structure and function of the $\mathrm{N}$-cycling microbial community. The ISME Journal 2013;8:1-15.

93. Hossain MK, Strezov V, Chan KY, Nelson PF. Agronomic properties of wastewater sludge biochar and bioavailability of metals in production of cherry tomato (Lycopersicon esculentum). Chemosphere 2010;78:1167-1171.

94. Liu X, Zhang A, Ji C, Joseph S, Bian R, Li L. Biochar's effect on crop productivity and the dependence on experimental conditions-a meta-analysis of literature data. Plant and Soil 2013;373:583-594.

95. Cheng C, Lehmann J, Thies J, Burton S, Engelhard M. Oxidation of black carbon by biotic and abiotic processes. Organic Geochemistry 2006;37:1477-1488.

96. Cheng $\mathrm{CH}$, Lehmann J, Engelhard $\mathrm{MH}$. Natural oxidation of black carbon in soils: Changes in molecular form and surface charge along a climosequence. Geochimica et Cosmochimica Acta 2008;72:1598-1610.

97. Liang B, Lehmann J, Solomon D, Kinyangi, J, Grossman J, O'Neill B, et al. Black carbon increases cation exchange capacity in soils. Soil Science Society of America Journal 2006;70:1719-1730.

98. Jones DL, Rousk J, Edwards-Jones G, DeLuca TH, Murphy DV. Biochar-mediated changes in soil quality and plant growth in a three year field trial. Soil Biology \& Biochemistry 2012;45:113124.

99. Bates BC, Kundzewicz ZW, Wu S, Palutikof JP. Climate Change and Water. Technical Paper of the Intergovernmental Panel on Climate Change, IPCC Secretariat, Geneva, 2008. p. 210.

100. Lehmann J, Kern D, German L, McCann, Martins GC, Moreira A. Soil fertility and production potential. In: Lehmann J, Kern DC, Glaser B, Woods WI editors. Amazonian Dark Earths: Origin, Properties, Management. Dordrecht: Kluwer Academic Publishers; 2003c p. 159-178.

101. Teixeira WG, Martins GC (2003). Soil physical characterization. In: Lehmann J, Kern DC, Glaser B, Woods WI, editors. Amazonian Dark Earths Origin Properties Management. Dordrecht: Kluwer Academic Publishers; 2003. p. 271-286.

102. Glaser B, Guggenberger G, Zech W. Identifying the Pre-Columbian Anthropogenic input on present soil properties of Amazonian Dark Earths (Terra Preta). In: Glaser B, Woods WI, Verlag S, Heidelberg B, editors. Amazonian Dark Earths: Explorations in Space and Time. Berlin: Springer; 2004. 
This material has been published in CAB Reviews (2014), Vol. 9 issue 19 pp. 1-19, the only accredited archive of the content that has been certified and accepted after peer review. Copyright and all rights therein are retained by CABI. www.cabi.org/CABReviews

103. Glaser B, Guggenberger G, Zech W, de Lourdes Ruivo M. Soil organic matter stability in Amazonian dark earths. In: Lehmann J, Kern DC, Glaser B, Woods WI, editors. Amazonian Dark Earths Origin Properties Management. Dordrecht: Kluwer Academic Publishers; 2003. p 141158.

104. Kampf N, Woods WI, Sombroek W, Kern DC, Cunha TJF. Calssification of Amazonian dark earths and other ancient anthropic soils. In: Lehmann J, Kern DC, Glaser B, Woods WI, editors. Amazonian Dark Earths Origin Properties Management. Dordrecht: Kluwer Academic Publishers: 2003. p. 77-102.

105. McKeya S, Rostain S, Iriartec J, Glaser B, Birk JJ, Irene Holste I, et al. Pre-Columbian agricultural landscapes, ecosystem engineers, and self-organized patchiness in Amazonia. Proceeding of the National Academy of Science 2010;107:7823-7828.

106. Lehmann J, Joseph S. Biochar for Environmental Management, Science and Technology. London: Earthscan; 2009.

107. Downie A, Crosky A, Munroe P. Physical properties of biochar. In: Lehmann J, Jospeh S, editors. Biochar for Environmental Management Science and Technology. London: Earthscan; 2009 p. 13-32.

108. Major J, Steiner C, Downie A, Lehmann J (2009). Biochar effects on nutrient leaching. In: Lehmann J, Joseph S. editors. Biochar for Environmental Management Science and Technology. London: Earthscan; 2009. p. 271-287.

109. Jha P, Biswas AK, Lakaria BL, Rao AS. Biochar in agriculture - prospects and related implications. Current Science 2010;99:1218-1225.

110. Laird D. The charcoal vision: a win-win-win scenario for simultaneously producing bioenergy, permanently sequestering carbon, while improving soil and water quality. Agronomy Journal 2008;100:178-181.

111. Dıaz-Teran J, Nevskaia DM, Lopez-Peinado AJ, Jerez A. Porosity and adsorption properties of an activated charcoal Colloids and Surfaces. Physicochemical and Engineering Aspects 2001;187-188:167-175.

112. Keech O, Carcaillet C, Nilsson M-C. Adsorption of allelopathic compounds by wood-derived charcoal: the role of wood porosity. Plant and Soil 2005;272:291-300.

113. Pignatello JJ, Kwon S, Lu Y. Effect of natural organic substances on the surface and adsorptive properties of environmental black carbon (Char): attenuation of surface activity by humic and fulvic acids. Environmental and Science Technology 2006;40:7757-7763.

114. Song W, Guo M. Quality variations of poultry litter biochar generated at different pyrolysis temperatures. Journal of Analytical and Applied Pyrolysis 2012;94:138-145.

115. Tyron EH. Effects of charcoal on certain physical, chemical and biological properties of forest soils. Ecological Monographs 1948;18:82-115. 
This material has been published in CAB Reviews (2014), Vol. 9 issue 19 pp. 1-19, the only accredited archive of the content that has been certified and accepted after peer review. Copyright and all rights therein are retained by $C A B I$. www.cabi.org/CABReviews

116. Graber ER, Harel YM, Kolton M, Cytryn E, Silber A, David DR, Tsechansky L, Borenshtein M, Elad $Y$. Biochar impact on development and productivity of pepper and tomato grown in fertigated soilless media. Plant and Soil 2010;337:481-496.

117. Chen $Y$, Shinogi $Y$, Taira M. Influence of biochar use on sugarcane growth, soil parameters, and groundwater quality. Australian Journals of Soil Research 2010;48:256-530.

118. Abel S, Peters A, Trinks S, Schonsky H, Facklam M, Wessolek G. Impact of biochar and hydrochar addition on water retention and water repellency of sandy soil. Geoderma 2013;202-203:183-191.

119. Mulcahy DN, Mulcahy DL, Dietz D. Biochar soil amendment increases tomato seedling resistance to drought in sandy soils. Journal of Arid Environments 2013;88:222-225.

120. Herath HMSK, Camps-Arbestain M, Hedley M. Effect of biochar on soil physical properties in two contrasting soils: An Alfisol and an Andisol. Geoderma 2013;209-210:188-197.

121. Baronti S, Vaccari FP, Miglietta F, Calzolari C, Lugato E, Orlandini S, et al. Impact of biochar application on plant water relations in Vitis vinifera (L.). European Journal of Agronomy 2014;53:38-44.

122. Yanai $\mathrm{Y}$, Toyota $\mathrm{K}$, Okazaki $\mathrm{M}$. Effects of charcoal addition of $\mathrm{N}_{2} \mathrm{O}$ emissions from soil resulting from rewetting air-dried soil in short-term laboratory experiments. Soil Science and Plant Nutrition 2007;53:181-188.

123. Bateman EJ, Baggs EM. Contributions of nitrification and denitrification to $\mathrm{N}_{2} \mathrm{O}$ emissions from soils at different water-filled pore space. Biology and Fertility of Soils 2005;41:379-388.

124. Warnock DD, Lehmann J, Kuyper TW, Rillig MC. Mycorrhizal responses to biochar in soil concepts and mechanisms. Plant and Soil 2007;300:9-20.

125. Nguyen BT, Lehmann J. Black carbon decomposition under varying water regimes. Organic Geochemistry 2009;40:846-853.

126. Karhu K, Mattila T, Bergstrom I, Regina K. Biochar addition to agricultural soil increased $\mathrm{CH}_{4}$ uptake and water holding capacity - Results from a short-term pilot field study. Agriculture, Ecosystems and Environment 2011;140:309-313.

127. Yu L, Tang J, Zhang R, Wu Q, Gong M. Effects of biochar application on soil methane emission at different soil moisture levels. Biology and Fertility of Soils 2013;49:119-128.

128. Lim S-S, Choi W-J. Changes in microbial biomass, $\mathrm{CH}_{4}$ and $\mathrm{CO}_{2}$ emissions, and soil carbon content by fly ash co-applied with organic inputs with contrasting substrate quality under changing water regimes. Soil Biology and Biochemistry 2014;68:494-502.

129. Sorensen LH. Rate of decomposition or organic matter in soil as influenced by repeated air drying-rewetting and repeated additions of organic material. Soil Biology and Biochemistry 1974;6:287-292.

130. Van Gestel M, Merckx R, Vlassak K. Microbial biomass responses to soil drying and rewetting: the fate of fast- and slow-growing microorganisms in soils from different climates. Soil Biology and Biochemistry 1993;25:109-123. 
This material has been published in CAB Reviews (2014), Vol. 9 issue 19 pp. 1-19, the only accredited archive of the content that has been certified and accepted after peer review. Copyright and all rights therein are retained by CABI. www.cabi.org/CABReviews

131. Nguyen BT, Marschner P. Effects of drying and rewetting on phosphorus transformations in red brown soils with different soil organic matter content. Soil Biology and Biochemistry 2005;37:1573-1576.

132. Shinogi $Y$, Kanri Y. Pyrolysis of plant, animal and human waste: physical and chemical characterization of the pyrolytic products. Bioresource Technology 2003;90:241-247.

133. Mullen CA, Boateng AA, Goldberg NM, Lima IM, Laird D, Hicks KB. Bio-oil and bio-char production from corn cobs and stover by fast pyrolysis. Biomass and Bioenergy 2010;34:67-74.

134. Joseph SD, Camps-Arbestain M, Lin $Y$, Munroe $P$, Chia $C H$, Hook J, van Zwieten L, Kimber S, Cowie A, Singh BP, Lehmann J, Foidl N, Smernik RJ, Amonette JE. An investigation into the reactions of biochar in soil. Australian Journal of Soil Research 2010; 48:501-515

135. Kinney TJ, Masiello CA, Dugan B, Hockaday WC, Dean MR, Zygourakis K, Barnes RT. Hydrologic properties of biochars produced at different temperatures. Biomass and Bioenergy 2012;41:34-43.

136. Novak JM, Watts DW. Augmenting soil water storage using uncharred switchgrass and pyrolyzed biochars. Soil Use and Management 2013;29:98-104.

137. Sun H, Hockaday WC, Masiello CA, Zygourakis K. Multiple Controls on the Chemical and Physical structure of Biochars. Industrial Engineering and Chemical research 2012;51:35873597.

138. Azargohor R, Dalai AK. Steam and KOH activation of biochar: Experimental modelling studies. Microporous Mesoporous Matter 2008;110:413-421.

139. Tian $Y$, Sun $X$, Li S, Wang $H$, Wang L et al. Biochar made from green waste as peat substitute in growth media for Calathea rotundifola cv. Fasciata. Scientia Horticulturae 2012;143:15-8.

140. Vaccari FP, Baronti S, Lugato E, Genesio L, Castaldi S, Fornasier F et al. Biochar as a strategy to sequester carbon and increase yield in durum wheat. European Journal of Agronomy 2011;34:231-238.

141. Dumroese RK, Heiskanen J, England K, Tervahauta A. Pelleted Biochar: Chemical and physical properties show potential use as a substrate in container nurseries. Biomass and Bioenergy 2011;35:2018-2027.

142. Laird D, Fleming P, Davis DD, Horton R, Wang B, Karlen DL. Impact of biochar amendments on the quality of a typical Midwestern agricultural soil. Geoderma 2010;158:443-449. 
This material has been published in CAB Reviews (2014), Vol. 9 issue 19 pp. 1-19, the only accredited archive of the content that has been certified and accepted after peer review. Copyright and all rights therein are retained by CABI. www.cabi.org/CABReviews 